\title{
The impact of infectious disease in war time: a look back at WW1
}

\author{
Hugh Pennington*,1 \\ ${ }^{1}$ Emeritus Professor of Bacteriology, University of Aberdeen, 13 Carlton Place, Aberdeen AB15 4BR, UK \\ *Author for correspondence: t.h.pennington@abdn.ac.uk
}

\section{"As microbiologists it is worth looking back to WW1, not only as a job not badly done, but one with lessons still to teach."}

First draft submitted: 21 November 2018; Accepted for publication: 17 December 2018; Published online: 10 January 2019

Keywords: bacteriology $\bullet$ disease $\bullet$ influenza $\bullet$ trench fever $\bullet$ typhus $\bullet$ World War 1

World War 1 (WW1) ended a century ago, at the 11th hour on the 11th day on the 11th month of 1918. Millions of combatants had died but it was the first big war in history in which more were killed by military action than by infectious diseases. Why?

In 1914, bacteriology had matured as a science. There were no antibiotics, but the majority of important pathogens had been discovered and made amenable to laboratory investigation. Alexander Fleming spent the war studying wound infections in the British Army General Hospital that had taken over Boulogne Casino (France); microbiology was having an impact. Far fewer British and Dominion troops died of disease $(113,000)$ than from shells and bullets; 418,000 were killed in action, many tens of thousands were missing, and 167,000 died from wounds [1]. The statistics for the German Army showed a similar ratio with 1,531,048 killed in battle, and 155,013 died of disease.

\section{War deaths before WW1}

In contrast, in the Crimean War (1854-1856; 730,000 British, French and Russian combatants) 34,000 were killed in action, 26,000 died from wounds and 130,000 died from diseases, with contemporaneous diagnoses of cholera and typhus fever being recorded as particularly important causes [1]. The ratio of deaths from disease and those from missiles and bullets was much the same in the British Army in its first big 20th century war - the South African War (1899-1902). The average annual strength of the army during the war was 210,000, of whom 5774 were killed in action, 2018 died of wounds and 13,250 died of disease, of which 8227 were killed by typhoid fever [2]. For many years, typhoid was seen as one of the greatest scourges of armies mobilized for war; it was not just a British phenomenon. In the 10-week Spanish-American war (1898), 2192 US soldiers died from typhoid compared with 379 who died in combat.

\section{Typhoid in WW1}

In WW1 on the Western front, typhoid was no longer a general military problem; only 260 British soldiers there had died from typhoid and paratyphoid, during the whole war. Contemporary microbiologists gave the credit to killed vaccines [3].

It is far more likely however, that the provision of clean drinking water to soldiers in the trenches and in camps away from the front line was actually responsible. The lesson from the South African War had been learned. The capture and destruction by the Boers of Bloemfontein Waterworks in the Orange Free State (1900) obliged soldiers to use contaminated wells in the town which resulted in an outbreak of typhoid, leading to 1800 deaths [4].

\section{Trench fever in WW1}

Soldiers died in the trenches from shell fire, not transmissible infections. As the war historian, Sir Hew Strachan has said, "Trenches saved lives. To speak of the horror of the trenches is to substitute hyperbole for common sense: the war

Future $\because$ Medicine 
would have been far more horrific if there had been no trenches. They protected flesh and blood from the worst effects of the firepower revolution of the late 19th century" [5]. However, nonlethal conditions in the unwounded living there became an enormous problem and some had serious effects on military efficiency. Trench fever, for example, which was first described in 1915, was the cause of a fifth of admissions to casualty clearing stations by 1917. Its most famous victim was AA Milne, author of Winnie-the-Pooh. Today, some claim that he had post-traumatic stress disorder because he was invalided home after working in no-man's land as a Signals Officer during the battle of the Somme (France) (1916). In reality, it was trench fever that sent him home. Trench fever transmission was through body louse, not by bite, but by inoculation of louse feces during scratching. Headaches, severe shin pain with tenderness, splenomegaly, an evanescent rash and a fever that came and went for weeks were its hallmarks. Incapacitation often lasted 60-70 days and was ubiquitous because lousiness was almost universal in the trenches. One study in 1915 found that $95 \%$ of soldiers were infested with an average lousiness of 20 lice per man and with 5\% having 100-300 lice each [6]; an example of parasite aggregation in which most individuals carry few and a few carry the majority of the parasite population [7]. Lice primarily infest clothes. Kilts, with their many folds, were notorious as dwellings for them; dugouts helped because men huddled together. The luckiest soldiers were those based near coal mines in northern France whom had used the pit head baths, but disinfecting clothes effectively needed steam or hot air generated in big chambers, which could not be located near the front. They only came into their own at the end of the war, during demobilization, when men were disinfected at special camps, at English Channel ports prior to departure from France.

\section{Trench fever today}

Eventually, trench fever seemed to disappear and was deemed to be a WW1 curiosity [8]. Volunteer and autoinoculation studies by researchers during WW1 had demonstrated infectivity, and rickettsial-like inclusions had been seen in lice, louse feces and louse intestines collected from trench fever patients, so the agent was called Rickettsia quintana. It was first-grown culture in 1961 [9], enabling serological surveys and sequencing of its genome; it is now called Bartonella quintana. Paleomicrobiology has found it in the dental pulp from Napoleonic soldiers buried in Lithuania in 1812, and serosurveys have found it to be reasonably common in rural Andean communities in Peru. It has also been found in lice from homeless persons in San Francisco, Tokyo, Moscow, Burundi and Marseilles [10].

Trench fever, like shell shock and related conditions, paradoxically saved lives as they made soldiers unfit for duty in the front line; its possible there is a direct link between them. We now know that B. quintana can cause endocarditis. 'Disorderly action of the heart' or 'soldier's heart' was a shell-shock variant. First described in the American Civil War as 'Da Costa's syndrome', many thought that its cardiac symptoms were caused by anxiety. How many were due to $B$. quintana we will never know, but it is a reasonable guess that more than a few were.

\section{Typhus in WW1}

Our commemorations of WW1 focus on fighting in France and Belgium, but the conflict started in the Balkan Wars, when Austria-Hungary declared war on Serbia (1914). Belgrade had changed hand twice by early 1915 when an enormous typhus epidemic started and killed at least 150,000 in Serbia, causing military activity on both sides to be suspended for 6 months. The American Red Cross sent a sanitary commission to Serbia [11], with Hans Zinsser as the bacteriologist. In his minor classic, 'Rats, Lice and History' he states, "Among the most remarkable phenomena of the war is the total absence of typhus from the Western Front. No completely satisfactory explanation for this can be offered. Soldiers in the trenches on this front were as universally lousy as soldiers have always been" [12]. There is a likely explanation: typhus fever in the UK in 1914 was approaching extinction, so soldiers were not taking it with them from home to war. Even in Glasgow, one of its hot spots, mortality rates from it had fallen by more than $99 \%$ by 1910 , and diagnosticians were actually worried that because it was so rare, medical students would see none before graduation [13].

\section{Gas gangrene}

Trench fever took army medical staff by surprise, as did gas gangrene. The development of gangrene was frequent after pre-Listerian surgery, but had become rare. In 1914, more than $12 \%$ of wounded members of the British expeditionary force developed it but by 1918, it had fallen to less than 1\% [14]. Rapid evacuation of the wounded and speedy wound debridement was crucial. Tetanus was much less common, with the total number of British wounded on all fronts being 2,032,142 and of these only 2385 had developed tetanus. At its peak in September 
1914, a ratio of 9 cases of tetanus per 1000 wounded was estimated [14] and by October 1918, it was 0.5. Passive immunization with antitoxin had become general by mid-October 1914.

\section{Influenza}

At the end of the war, came influenza. A spring wave began in March 1918, spreading through Europe, the USA and Asia over the following 3 months. It infected many, but mortality rates were unexceptional. The second wave spread globally from September to November; lethality was its hallmark. Not only did it kill the young and the old, there was also a peak of deaths in young adults aged 20-40, with half the deaths in the second wave occurring in this age group. In many, their illnesses moved rapidly from typical influenza to lethal pneumonia. US military data on this are particularly detailed [15]. Respiratory diseases killed 46,992 soldiers during the war, mostly from pneumonia. A fulminant course with 'heliotrope' cyanosis was characteristic, but attempts to prevent the spread of infection in military camps in the USA were unsuccessful, with both quarantine and face masks not working and antiseptic gargles increasing the incidence of infection.

American Expeditionary Forces battle deaths totaled 50,385 [15].

The impact of influenza on the war is unclear. None of the politicians and generals seemed to get infected, although there is a rumor that Woodrow Wilson may have suffered, but recovered. It is uncertain whether troop movements aided the spread of the virus and we will never know the total death toll from it. Uncertainty about war statistics varies. For example, gas gangrene is a clinical diagnosis and figures for it are reasonably reliable but trench fever was not formally recorded, and laboratory tests were not developed for another half a century.

\section{Current memories of WW1}

"The popular view of the First World War is dominated by cliché: young British soldiers, many of them budding poets, led to early and ghastly deaths in muddy wastes... " [5]. "Of the trench words like trench mouth, trench foot, trench knife and trench coat, only trench fever has not survived" [16]. But our memories let us down. As microbiologists it is worth looking back to WW1, not only as a job not badly done, but one with lessons still to teach.B. quintana has not gone away, and it is a reminder that if vector control falls to a low priority, pathogens will take advantage, like Zika virus in Brazil. There is talk of 'falling back into the preantibiotic era' because of microbial resistance, but without them and with scrupulous attention to asepsis, WW1 outcomes were not bad; 4178 US soldiers had amputations because of bone injuries and only 187 died meaning there was a mortality rate of $4.47 \%$ [17].

\section{The legacy of 1918}

We still commemorate the Armistice but for microbiologists the biggest abiding memory of that year is the influenza pandemic. Its lethality still sends shivers down our spines, and has deeply embedded the precautionary principle into our thinking, with subsequent discoveries and developments compounding our difficulties. In 1918, avian influenza was well understood but was called fowl plague and thought to infect only birds meaning there was no flu vaccine as safety questions did not arise.

Despite many decades of research, our predictive ability is still little better than those who went to war in 1914 expecting it to be over by Christmas. The death of a US soldier in 1976 from swine flu was thought to presage the imminent return of the 1918 virus. It led to a massive US vaccination program but the virus never spread further. There was no pandemic [18], but there will be one in the future. Evolution will see to that [19].

\section{Financial \& competing interests disclosures}

The authors have no relevant affiliations or financial involvement with any organization or entity with a financial interest in or financial conflict with the subject matter or materials discussed in the manuscript. This includes employment, consultancies, honoraria, stock ownership or options, expert testimony, grants or patents received or pending, or royalties.

No writing assistance was utilized in the production of this manuscript.

\section{References}

1. Cooter R. War and modern medicine. In: Companion Encyclopedia of the History of Medicine. Bynum WF, Porter R (Eds). Routledge, Abingdon, UK (1993).

2. Amery LS, Williams B, Tallboy GP, Childers E. The Times History of the War in South Africa, 1899-1902 S. Low, Marston, Limited 7, 25 (1905).

3. Leishman WB. Enteric fevers in the British Expeditionary Force. JRAMC 37(1), 1-22 (1921). 
4. De Villiers JC. Healers, Helpers and Hospitals, Protea Book House Pretoria, South Africa Vol. 2, 102-131 (2008).

5. Strachan H. The First World War. Simon and Schuster, New York City, New York, USA (2014).

6. Macpherson WG, Beveridge WWO, Horrocks WH. Medical Services: Hygiene of the War. HM Stationery Office, 2, 327-388 (1923).

7. Gourbière S, Morand S, Waxman D. Fundamental factors determining the nature of parasite aggregation in hosts. PLoS ONE 10(2), e0116893 (2015).

8. Atenstaedt RL. Trench fever: the British medical response in the Great War. J. R. Soc. Med. 99(11), 564-568 (2006).

9. Vinson JW. In vitro cultivation of the rickettsial agent of trench fever. Bull. World Health Org. 35(2), 155-164 (1966).

10. Bonilla DL, Kabeya H, Henn J, Kramer VL, Kosoy MY. Bartonella quintana in body and head lice from homeless persons, San Francisco, California, USA. Emerg. Infect. Dis. 15(6), 912-915 (2009).

11. Strong RP, Shattuck GC, Sellards AW, Zinsser H, Hopkins JG. Typhus Fever, With Particular Reference to the Serbian Epidemic. Harvard University Press, Cambridge, MA (1920).

12. Zinsser H. Rats, Lice, and History: Being a Study in Biography, Which, After Twelve Preliminary Chapters Indispensable for the Preparation of the Lay Reader, Deals with the Life History of Typhus Fever. . . Routledge, Abingdon, UK (1942).

13. Chalmers AK. The Health of Glasgow, 1818-1925. An Outline. Glasgow Corporation, Glasgow, Scotland, 297-300 (1930).

14. Wilson GS, Miles AA. Topley and Wilson's Principles of Bacteriology, Virology and Immunity, Vol. 2 (6th Edition), London, UK, 2258-2259 (1975).

15. Siler JF. Inflammatory diseases of the respiratory tract, (bronchitis; influenza; bronchopneumonia; lobar pneumonia). In: The Medical Department of the United States Army in the World War, Vol 9, Communicable and Other Diseases. US Government Printing Office, Washington, USA, 61-169 (1928).

16. Fussell P. The Great War and Modern Memory. Oxford University Press, Oxford, New York, UK, 189 (1975).

17. Pennington TH. Have Bacteria Won? Polity Press, Cambridge, UK (2016).

18. Neustadt RE, Fineberg H. The Epidemic that Never Was. Vintage Books, New York, USA (1983).

19. Pennington TH. Microbes evolve, microbes survive. Future Microbiol. 13(1), 1-2 (2006). 